\title{
ABSOLUTE RADIOMETRIC CALIBRATION OF THE GÖKTÜRK-2 SATELLITE SENSOR USING TUZ GÖLÜ (LANDNET SITE) FROM NDVI PERSPECTIVE
}

\author{
Ufuk Sakarya, İsmail Hakkı Demirhan, Hüsne Seda Deveci, Mustafa Teke, Can Demirkesen, Ramazan Küpçü, A. Feray Öztoprak, \\ Mehmet Efendioğlu, F. Fehmi Şimşek, Erdinç Berke, Sevgi Zübeyde Gürbüz \\ TÜBİTAK UZAY (The Scientific and Technological Research Council of Turkey, Space Technologies Research Institute), ODTÜ \\ Yerleşkesi, 06800, Ankara, Turkey - (ufuk.sakarya, hakki.demirhan, seda.deveci, mustafa.teke, can.demirkesen, ramazan.kupcu, \\ feray.oztoprak, mehmet.efendioglu, fehmi.simsek, erdinc.berke, sevgi.gurbuz) @ tubitak.gov.tr
}

\author{
Commission I, WG I/4
}

KEY WORDS: Absolute radiometric calibration; Göktürk-2, Tuz Gölü, NDVI

\begin{abstract}
:
TÜBİTAK UZAY has conducted a research study on the use of space-based satellite resources for several aspects of agriculture. Especially, there are two precision agriculture related projects: HASSAS (Widespread application of sustainable precision agriculture practices in Southeastern Anatolia Project Region (GAP) Project) and AKTAR (Smart Agriculture Feasibility Project). The HASSAS project aims to study development of precision agriculture practice in GAP region. Multi-spectral satellite imagery and aerial hyperspectral data along with ground measurements was collected to analyze data in an information system. AKTAR aims to develop models for irrigation, fertilization and spectral signatures of crops in Inner Anatolia. By the end of the project precision agriculture practices to control irrigation, fertilization, pesticide and estimation of crop yield will be developed. Analyzing the phenology of crops using NDVI is critical for the projects. For this reason, absolute radiometric calibration of the Red and NIR bands in space-based satellite sensors is an important issue. The Göktürk-2 satellite is an earth observation satellite which was designed and built in Turkey and was launched in 2012. The Göktürk-2 satellite sensor has a resolution 2.5 meters in panchromatic and 5 meters in R/G/B/NIR bands. The absolute radiometric calibration of the Göktürk-2 satellite sensor was performed via the ground-based measurements spectra-radiometer, sun photometer, and meteorological station- in Tuz Gölü cal/val site in 2015. In this paper, the first ground-based absolute radiometric calibration results of the Göktürk-2 satellite sensor using Tuz Gölü is demonstrated. The absolute radiometric calibration results of this paper are compared with the published cross-calibration results of the Göktürk- 2 satellite sensor utilizing Landsat 8 imagery. According to the experimental comparison results, the Göktürk-2 satellite sensor coefficients for red and NIR bands estimated in this work sustained to agree within $2 \%$ of calibration coefficients estimated in the cross-calibration results.
\end{abstract}

\section{INTRODUCTION}

Radiometric calibration is essential to ensuring the quality of data obtained from space assets as well as the inter-operability of data obtained from different satellites, especially for earth observation applications. Calibration is defined by the Committee of Earth Observation Satellites (CEOS) as "the process of quantitatively defining the system response to known, controlled signal inputs" (CEOS 2016). Most applications involve using satellite imagery to measure or extract information about some physical characteristic of the earth's surface. Using an optical satellite as an example, the pixel values of an image, i.e. the digital signal, digital number (DN) obtained from a satellite, are related to the radiance of a scene on the earth's surface only after going through a number of transformations. The top-of-atmosphere (ToA) radiance measured by a space-borne sensor is the sum of a number of radiance sources, including direct solar radiation reflected from the ground to the sensor, scattered, direct and indirect reflections, as well as upwelled radiance scattered from the atmosphere to the sensor. Meaningful interpretation of satellite data requires relating the surface radiance to the ToA radiance, as well as characterization of the sensor to account for any distortion due to the satellite optics, detector and electronics that may occur during the process of forming the satellite image. It is only through radiometric calibration - a calibration of the measurements relating to electromagnetic radiation at all wavelengths - that pixel values of an image can be related to physically meaningful quantities.
Absolute radiometric calibration, more specifically, refers to the conversion of the digital number (DN) of a pixel to absolute units, such as percentage reflectance value by using ground measurements of surface reflectance and atmospheric conditions to generate a radiative transfer code, which is in turn used to predict the sensor spectral radiance and is compared with coincident satellite imagery. Ground measurements are related to the ToA atmospheric measurements made by the satellite through radiative transfer models, such as $6 \mathrm{~S}$ (Vermote et al. 1997), (6S 2016), MODTRAN (Anderson et al. 2002). The gain and offset values of the satellite are adjusted so as to make the DN values corresponding the ToA measurements consistent with the radiometric measurements taken from the ground. In this way, the DN values are tied to physically meaningful surfacebased values, which can then be exploited for a plethora of remote sensing applications.

There are numerous works in absolute radiometric calibration of multispectral sensors. Slater et al. (Slater et al. 1987) proposed reflectance-based and radiance-based absolute radiometric calibration of multispectral sensors. The results were presented for the Landsat $5 \mathrm{TM}$ in a $2.8 \%$ standard deviation for the six solar reflective bands. Slater et al. (Slater et al. 1996) demonstrated four methods for the in-flight radiometric calibration and cross calibration of multispectral imaging sensors. Naughton et al. (Naughton et al. 2011) realized absolute radiometric calibration of the RapidEye multispectral sensor 
using reflectance-based vicarious calibration method at Railroad Valley Playa. Czapla-Myers et al. (Czapla-Myers et al. 2015) presented the vicarious calibration results of Landsat 8 OLI using the reflectance-based approach. Kim et al. (Kim et al. 2015) presented the vicarious radiometric calibration of KOMPSAT-3 sensor.

The Scientific and Technological Research Council of Turkey Space Technologies Research Institute (TÜBİTAK UZAY) is focused on space and information technologies as system and subsystem level developer and integrator, keeping abreast of latest technological developments. TÜBITTAK UZAY is leading of the design, development, integration, test and operations of Earth Observation satellites as well as image-data processing and developing Earth Observation applications and services for end users in Turkey. TÜBİTAK UZAY has conducted a research study on the use of space-based satellite resources for several aspects of agriculture. Especially, there are two precision agriculture related projects: HASSAS (Widespread application of sustainable precision agriculture practices in Southeastern Anatolia Project Region (GAP) Project) and AKTAR (Smart Agriculture Feasibility Project) (Sakarya et al. 2015b). The HASSAS project aims to study development of precision agriculture practice in GAP region. Multi-spectral satellite imagery and aerial hyperspectral data along with ground measurements was collected to analyze data in an information system. AKTAR aims to develop models for irrigation, fertilization and spectral signatures of crops in Inner Anatolia. By the end of the project precision agriculture practices to control irrigation, fertilization, pesticide and estimation of crop yield will be developed. Analyzing the phenology of crops using NDVI (Normalized Difference Vegetation Index) is critical for these projects. For this reason, absolute radiometric calibration of red and NIR bands in space-based satellite sensors is important issue.

The Göktürk-2 satellite is an earth observation satellite which was designed and built in Turkey was launched in 2012. The Göktürk-2 satellite sensor has a resolution 2.5 meters in panchromatic and 5 meters in R/G/B/NIR bands. The absolute radiometric calibration of the Göktürk-2 satellite sensor was performed via the ground-based measurements -ASD FieldSpec3 spectro-radiometer, sun photometer, and meteorological stationin Tuz Gölü cal/val site in 2015. In this paper, the first groundbased absolute radiometric calibration results of the Göktürk-2 satellite sensor using Tuz Gölü is demonstrated. The absolute radiometric calibration results of this paper are also compared with the published cross-calibration results of the Göktürk-2 satellite sensor utilizing Landsat 8 imagery (Teke et al. 2016). According to the experimental comparison results, the Göktürk2 satellite sensor coefficients for red and NIR bands estimated in this work sustained to agree within $2 \%$ calibration coefficients estimated in the cross-calibration results.

The remainder of the paper is organized as follows: Section 2 gives information about the sensor, the test site and the measurements. Section 3 presents the ground-based absolute radiometric calibration method of the Göktürk-2 satellite sensor using Tuz Gölü. Section 4 demonstrates comparative performance results between the ground-based absolute radiometric calibration and the published cross-calibration results. Finally, Section 5 presents some concluding remarks and future research issues.

\section{THE SENSOR, THE TEST SITE AND MEASUREMENTS}

\subsection{The Sensor}

Göktürk-2 was launched in $12^{\text {th }}$ December 2012 . The Göktürk-2 satellite sensor has a resolution 2.5 meters in panchromatic and 5 meters in $\mathrm{R} / \mathrm{G} / \mathrm{B} / \mathrm{NIR}$ bands. The more detailed information about the sensor can be found in (Atak et al. 2015), (Teke 2016), (Teke et al. 2016).

\subsection{The Test Site}

Vicarious absolute radiometric calibration methods that use natural targets (such as salt lakes, deserts, or flatlands that have known uniform area) as a reference are well established, but must be selected so as to minimize sources of error for any given sensor. Committee on Earth Observation Satellites (CEOS) Working Group on Calibration and Validation (WGCV) Infrared and Visible Optical Sensors Group (IVOS) endorsed eight wellcharacterized, regularly instrumented test sites, now known as LANDET sites (LANDNET 2016).

It is significant that of these eight LANDNET sites, one resides within Turkey (Gürbüz et al. 2012). The Tuz Gölü test site $\left(38.83^{\circ}\right.$ lat., $33.33^{\circ}$ long.) is a permanent endorheic lake located in Central Anatolian plateau of Turkey. 150 southeast of Ankara and $105 \mathrm{~km}$ northeast of Konya. Thus, Tuz Gölü is easily accessible as well as logistically convenient, far from the influence of any bodies of water. During the summer, $95 \%$ of the water in the lake dries, leaving behind a smooth, uniform and flat $30-80 \mathrm{~cm}$ thick layer of salt over a region of $500 \mathrm{~km}^{2}$. It is possible to drive on the surface, but care must take to avoid the springs discharging saline groundwater, which form $1 \mathrm{~m}-1.5 \mathrm{~m}$ circular structures, covered by just a thin layer of salt crust, on the surface. There is no vegetation on the dry salt lake; however, the lake is surrounded by fields and salt steppes, with three salt works operating on the shore of the lake. In 2001, Tuz Gölü was declared an area of special protection, thereby preventing future infrastructure projects in the area. Tuz Gölü is a naturally bright target, with an average surface reflectance of 0.4-0.6 in the visible and near infrared bands (VIS/NIR), and 0.2 in the short wave infrared band (SWIR). An area of $324 \mathrm{~km}^{2}$ satisfies the homogeneity and reflectivity site selection criteria, making Tuz Gölü suitable for the calibration of low resolution as well as medium and high resolution sensors (Gürol, et. al., 2008), (Gürol, et. al., 2010). Limitations include high aerosol loading (optical thickness at $550 \mathrm{~nm}>0.1$ ) and the short period during the year for which the lake dries and is suitable for radiometric calibration measurements. Tuz Gölü 2014 Radiometric Calibration Campaign can be found in (Teke et al. 2015).

A vicarious calibration campaign was organized in Tuz Gölü $\mathrm{cal} / \mathrm{val}$ site on 10th and 11th September 2015. Coinciding with the campaign date, Göktürk-2 and Landsat 8 (USGS 2015) satellites acquired images. Landsat 8 (10/09/2015) and Göktürk$2(11 / 09 / 2015)$ acquired during Tuz Gölü 2015 Radiometric Calibration Campaign

\subsection{Measurements}

Field spectra were collected with ASD Field Spec-3. CIMEL sun photometer and Davis Vantage Pro2 PLUS meteorology station were used to measure environment parameters necessary to conduct absolute radiometric calibration. CIMEL sun photometer measures aerosol optical thickness and water vapor. Davis Vantage Pro2 PLUS meteorology station measures temperature, 
pressure and humidity needed for $6 \mathrm{~S}$ input. Ozone measurement at Tuz Gölü is also available on NASA's website. In addition, SATLAB SL600 was used the GNSS data for localization. The image of the collection of the field spectra can be seen on Figure 1. The image of the sun photometer and the meteorology station can be seen on Figure 2.

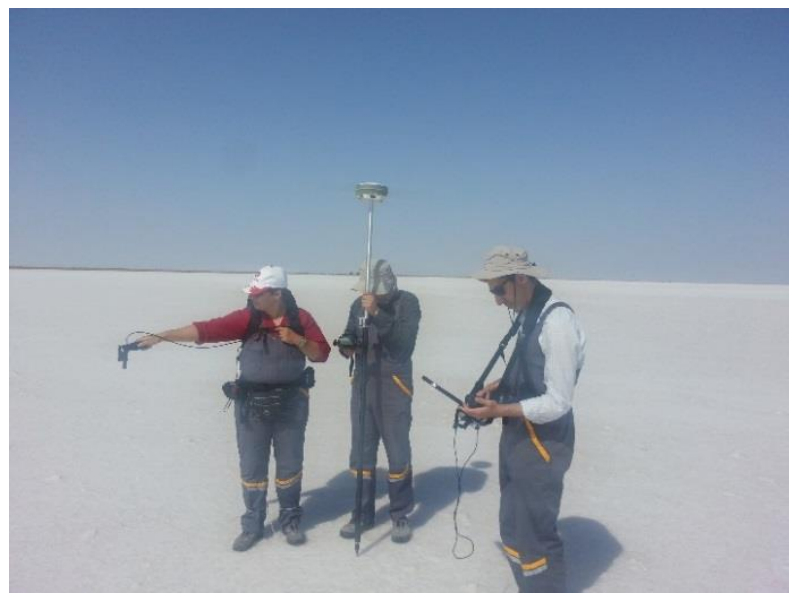

Figure 1. Surface reflectance measurements

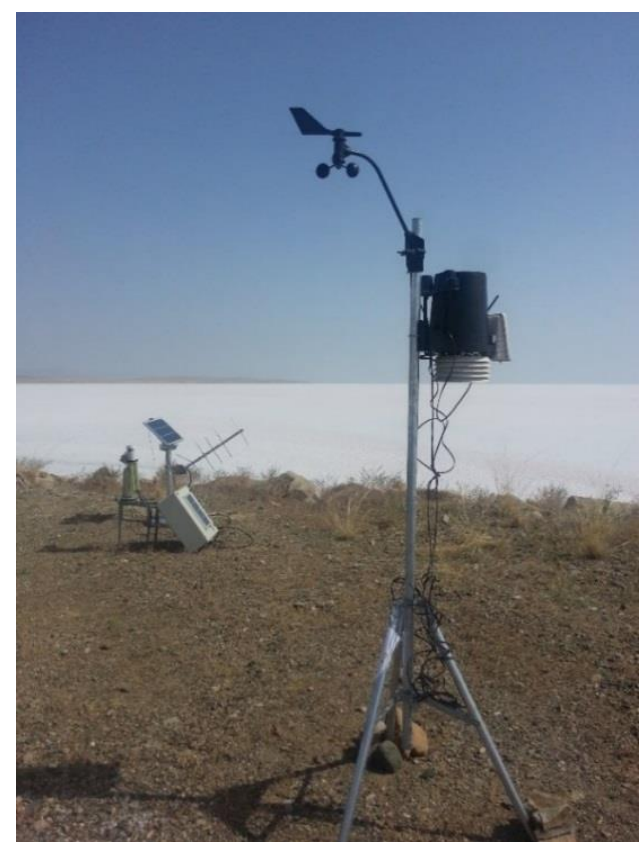

Figure 2. The sun photometer (left) and the meteorology station (right) used at Tuz Gölü September 2015

\section{METHOD}

A vicarious calibration campaign was organized in Tuz Gölü $\mathrm{cal} / \mathrm{val}$ site on 10th and 11th September 2015. For the campaign date, Göktürk- 2 and Landsat 8 satellites acquired images. System architecture of the ground-based absolute radiometric calibration method of the Göktürk-2 satellite sensor can be seen in Figure 3. A ground spectrum of the Tuz Gölü is converted to ToA radiance and satellite level radiance by computing radiative transfer modelling with 6S model (Vermote et al. 1997), (6S, 2016). Ground measurements are input to $6 \mathrm{~S}$ radiative transfer model. Digital numbers and their corresponding radiance values for each bands are used to solve to compute Gain and Offset parameters.

$$
\text { Radiance }=\text { Gain } * D N+\text { Offset }
$$

The $6 \mathrm{~S}$ radiative transfer model relies on geometric conditions, atmospheric model, spectral conditions, target \& sensor altitudes, signal source and ground reflectance measurements. Month, day, solar zenith, solar azimuth, view zenith and view azimuth angle parameters were used for the 6S geometric conditions. Atmospheric data including; water vapor, ozone and aerosol optical depth (at $550 \mathrm{~nm}$ ) measured at the site were used for the $6 \mathrm{~S}$ atmospheric model. Spectral response of Göktürk-2 satellite red and NIR bands were interpolated with $1 \mathrm{~nm}$ and $2.5 \mathrm{~nm}$ intervals for $6 \mathrm{~S}$ input format. The ground reflectance measurements in the range between 350 and $2500 \mathrm{~nm}$ wavelength were relationally regulated in order that the measurements are compatible with spectral response interpolated with 1 and $2.5 \mathrm{~nm}$ intervals. Then these sensor and ground reflectance data were used as input of $6 \mathrm{~S}$ spectral conditions; furthermore, we also used both satellite and target altitude parameters as inputs of $6 \mathrm{~S}$ measurements.

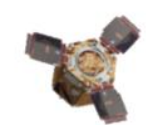

Satellite and Sensor Parameters
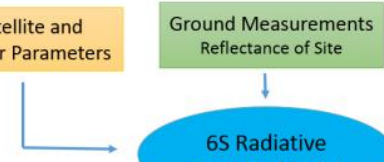
Reflectance of Site
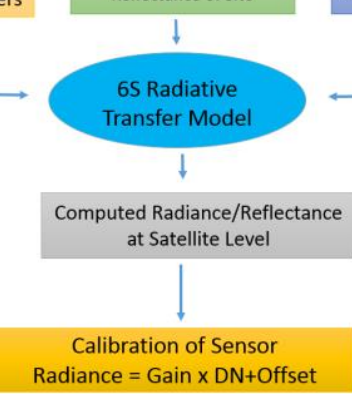

Rance $=$ Gain $\times$ DN + Offset
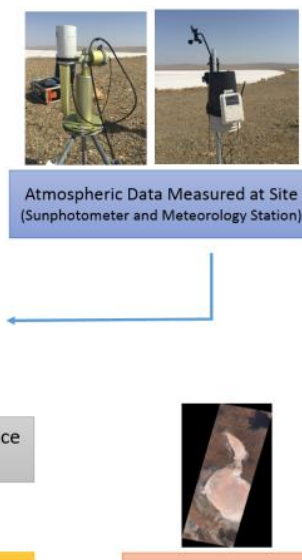

Atmospheric Data Measured at Site (Sunphotometer and Meteorology Station)

Ns from Image Data
Figure 3. System architecture of the ground-based absolute radiometric calibration method of the satellite sensor

All input parameters were given to $6 \mathrm{~S}$ as atmospheric model, spectral conditions, target $\&$ sensor altitude, ground reflectance measurements respectively. Some parameters like aerosol optical depth and visibility were changed according to input format of $6 \mathrm{~S}$.

\begin{tabular}{|c|l|}
\hline Measurements & Input Parameters \\
\hline Geometrical Conditions & $\begin{array}{l}\text { Day, month, view zenith, view } \\
\text { azimuth, sun zenith, sun azimuth }\end{array}$ \\
\hline Atmospheric Model & $\begin{array}{l}\text { Aerosol optical thickness, water } \\
\text { vapor, ozone }\end{array}$ \\
\hline Altitude Measurements & Target \& sensor altitudes \\
\hline Spectral Conditions & $\begin{array}{l}\text { Spectral response of Göktürk-2 } \\
\text { Red \& NIR bands (with 1 nm \& } \\
\text { 2,5 nm interval) }\end{array}$ \\
\hline Ground Measurements & $\begin{array}{l}\text { Ground reflectance } \\
\text { (with 1 nm \& 2,5 nm interval) }\end{array}$ \\
\hline
\end{tabular}

Table 1. 6S Input Parameters 
After radiance and reflectance values at satellite level (ToA) were computed by $6 \mathrm{~S}$, absolute radiometric calibration of sensor was done by $20 \mathrm{DN}$ data collected from image data. These $20 \mathrm{DNs}$ were step by step normalized with Göktürk- 2 sensor gain mode for red and NIR bands. Gain parameters for red and NIR bands estimated with linear regression analysis in this work. Offset parameters were fixed at bound as zero for both bands.

Before calculating vegetation indices, Göktürk-2 data was converted to ToA reflectance which is converted from radiancecalibrated data known as at- sensor spectral radiance that has vital importance to decrease scene to scene variations. Both gain values were multiplied with $\mathrm{DN}$ and converted to ToA radiance by equation in (1). Then calculation of ToA reflectance for Göktürk-2 Red and NIR bands was performed by following formula in (2), (Kalkan et al. 2015):

$$
\rho=\frac{\pi * L * d^{2}}{E_{S U N} * \cos \theta}
$$

$E_{S U N}:=$ Mean exoatmospheric solar irradiance

$L:=$ Spectral radiance at sensor's aperture

$d:=$ Earth Sun Distance

$\theta:=$ Solar Zenith Angle

$\rho:=$ Planetary ToA reflectance

The NDVI ratio is calculated by dividing the difference in the NIR and red color bands by the sum of the NIR and red colors bands for each pixel. ToA reflectance values for Göktürk-2 red and NIR bands calculated with formula in (2) are converted to NDVI by following formula in (3), (Kalkan et al. 2015).

$$
N D V I=\frac{(N I R-R e d)}{(N I R+R e d)}
$$

\section{RESULTS}

The ground-based absolute radiometric calibration results of Göktürk-2 (GbARC-GK2) are compared with the crosscalibration results -of the Göktürk-2 satellite sensor utilizing Landsat 8 imagery- given in (Kalkan et al. 2015). According to the experimental comparison results, the Göktürk-2 satellite sensor coefficients for red and NIR bands estimated in this work sustained to agree within $2 \%$ calibration coefficients estimated in the published cross-calibration results. The gain values for Göktürk-2 red and NIR bands can be seen in Table 2 .

\begin{tabular}{l|l|l} 
& Red & NIR \\
\hline GbARC-GK2 & 0.07624 & 0.08265 \\
\hline (Kalkan et al. 2015) & 0.07741 & 0.08255 \\
\hline Difference in \% & $1.51 \%$ & $0.12 \%$
\end{tabular}

Table 2. The gain values for Göktürk-2 red and NIR bands

The comparative analysis of NDVI values for both Landsat 8 and Göktürk- 2 imageries is examined by using 24 random points which are selected from vegetated area of the images. The comparative NDVI results of Landsat 8, Göktürk-2 -in which GbARC-GK2 gain parameter is used- and Göktürk-2 -in which (Kalkan et al. 2015) gain parameter is used-are presented in Figure 4. It must be noticed that Landsat 8 and Göktürk-2 acquired in different days (one day between). Therefore, this temporal difference can play an important role in NDVI differences.

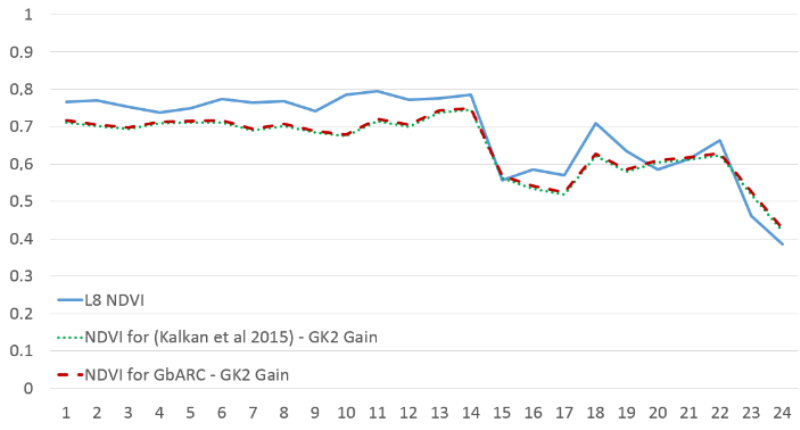

Figure 4. Comparison of NDVI values for test points

\section{CONCLUSIONS}

In this paper, the first ground-based absolute radiometric calibration results of the Göktürk-2 satellite sensor for Red \& NIR bands using Tuz Gölü is demonstrated. The absolute radiometric calibration results of this paper are compared with the published cross-calibration results of the Göktürk-2 satellite sensor utilizing Landsat 8 imagery. According to the experimental comparison results, the Göktürk-2 satellite sensor coefficients for red and NIR bands estimated in this work sustained to agree within $2 \%$ calibration coefficients estimated in the cross-calibration results.

Some issues in a ground-based absolute radiometric calibration of satellite sensors can be considered into account for future research directions. Hyperspectral remote sensing research and development activities are conducted in two main axes at TÜBİTAK UZAY, namely, hardware (Y1lmaz et al. 2015) and software (Sakarya et al. 2015a). The hardware studies include the design and manufacture of a new space-borne hyperspectral camera. Therefore, a ground-based absolute radiometric calibration of a space-borne hyperspectral camera can be considered into account for future research activity.

\section{ACKNOWLEDGMENTS}

This work is supported by Turkish Ministry of Development under funding of "Satellite Image Processing and Geoportal Development Project (GEOPORTAL)".

Authors would like to thank Turkish Air Force for providing Göktürk-2 satellite imagery. Authors would like to thank Bülent Avenoğlu for his valuable comments.

\section{REFERENCES}

6S Model, [Online] http://6s.Itdri.org, Accces date: 04.03.2016.

Anderson, G.P., Felde, G.W., Hoke, M.L., Ratkowski, A.J., Cooley, T.W., Chetwynd Jr., J.H., Gardner, J.A., Adler-Golden, S.M., Matthew, M.W., Berk, A., Bernstein, L.S., Acharya, P.K., Miller, D.P., Lewis, P.E., (2002) MODTRAN4-based atmospheric correction algorithm: FLAASH (fast line-of-sight atmospheric analysis of spectral hypercubes). Proc. SPIE 4725, Algorithms and Technologies for Multispectral, Hyperspectral, and Ultraspectral Imagery VIII, 65.

Atak, V. O., Erdoğan, M., \& Y1lmaz, A. (2015). Göktürk-2 Uydu Görüntü Testleri. Harita Dergisi, 81(2), 18-33.

CEOS, [Online] http://www.ceos.org, Accces date: 04.03.2016. 
Czapla-Myers, J., McCorkel, J., Anderson, N., Thome, K., Biggar, S., Helder, D., Aaron, D., Leigh, L., Mishra, N., (2015) The Ground-Based Absolute Radiometric Calibration of Landsat 8 OLI. Remote Sens. 7(1), 600-626.

Gürbüz, S.Z., Özen, H., Chander, G., (2012) A Survey of Landnet Sites Focusing on Tuz Gölü Salt Lake, Turkey. ISPRS Congress, Australia.

Gürol, S., Özen, H., Leloğlu, U.M., Tunal1, E., (2008). Tuz Gölü: New absolute radiometric calibration test site. Proceedings of the ISPRS Congress.

Gürol, S., Behnert, I., Özen, H., Deadman, A., Fox, N:, Leloğlu, U.M., (2010). Tuz Gölü: new CEOS reference standard test site for infrared visible optical sensors. Canadian J. Rem. Sens., Vol. 36, No. 5, pp. 553-565.

Kalkan, K., Özer, O., Filiz, B.G., Teke, M., (2015). Vegetation discrimination analysis from Göktürk-2 imagery, 7th International Conference on Recent Advances in Space Technologies (RAST 2015), pp.329-332, 16-19 June 2015.

Kim, J., Jin, C., Choi, C., Ahn, H., (2015). Radiometric characterization and validation for the KOMPSAT-3 sensor. Remote Sensing Letters, 6:7, pp. 529-538.

LANDNET SITES (CEOS Reference Sites), [Online] http://calvalportal.ceos.org/ceos-landnet-sites, Acces date: 04.03.2016.

Naughton, D., Brunn, A., Czapla-Myers, J., Douglass, S., Thiele, M., Weichelt, H., \& Oxfort, M., (2011). Absolute radiometric calibration of the RapidEye multispectral imager using the reflectance-based vicarious calibration method. Journal of Applied Remote Sensing, 5(1).

Sakarya, U., Teke, M., Demirkesen, C., Haliloğlu, O., Kozal, AÖ., Deveci, H.S., Öztoprak, A.F., Töreyin, B.U., Gürbüz, S.Z., (2015) A short survey of hyperspectral remote sensing and hyperspectral remote sensing research at TÜBİTAK UZAY. 7th International Conference on Recent Advances in Space Technologies (RAST 2015), İstanbul, Türkiye, pp. 187-192, 1619 June, 2015.

Sakarya, U., Teke, M., Demirkesen, C., Küpçü, R., Deveci, A.F. Öztoprak, A.F., Berke, E., Demirhan, İ.H., Efendioğlu, M., Kozal, A.Ö., Aras, E.S., Koru, A., Gürbüz, S.Z., (2015) Since 2012 to 2015: Remote Sensing Research at TÜBITAK UZAY. The 5th International Conference on Earth Observation for Global Changes (EOGC 2015) and the 7th International Conference on Geo-information Technologies for Natural Disaster Management (GiT4NDM 2015), pp. 52, United Arab Emirates University, Al-Ain, United Arab Emirates, 8th -10th December 2015.

Slater, P. N., Biggar, S. F., Holm, R. G., Jackson, R. D., Mao, Y., Moran, M. S., Palmer, J. M., Yuan, B., (1987). Reflectance- and radiance-based methods for the in-flight absolute calibration of multispectral sensors. Remote Sensing of Environment, Volume 22, Issue 1, pp. 11-37.

Slater, P. N., Biggar, S. F., Thome, K. J., Gellman, D. I., Spyak P. R., (1996). Vicarious radiometric calibrations of eos sensors. J. Atmos. Oceanic Technol., 13, pp. 349-359.
Teke, M., Tevrizoglu, I., Oztoprak, A.F., Demirkesen, C., Acikgoz, İ, Gurbuz, S.Z., Küpçü, R., Avenoğlu, B., (2015). GEOPORTAL:TÜBİTAK Uzay satellite data processing and sharing system, 7th International Conference on Recent Advances in Space Technologies (RAST 2015), İstanbul, Türkiye, pp. 233-238, 16-19 June, 2015.

Teke, M., Demirkesen, C., Haliloğlu, O., İmre, E., (2016). Göktürk-2 Uydusunun Bağll ve Mutlak Çapraz Radyometrik Kalibrasyonu (Relative and Absolute Cross Radiometric Calibration of Göktürk-2 Satellite), Harita Dergisi, 155,

Teke, M., (2016). Satellite Image Processing Workflow for RASAT and Göktürk-2, Journal of Aeronautics and Space Technologies, 9(1)

The USGS home page is http://www.usgs.gov, [Online], Accces date: 23.01.2015.

Vermote, E.F., Tanre, D., Deuze, J.L., Herman, M., and Morcrette, J.J., (1997), Second simulation of the satellite signal in the solar spectrum, 6S: An overview., IEEE Trans. Geosc. and Remote Sens. 35(3):675-686.

Yilmaz, O., Unses, E., Ucan, M., Buyuk, H., Celebi, M., Turk, F., Kirik, M., Haliloglu, O., Celik, V., Ekinci, M., Guven, E., Yilmaz, O., Acar, D., Aydogdu, M., Olca, M., Selimoglu, O., (2015) Current situation on spaceborne hyperspectral imager of TÜBİTAK Uzay: HSK. 7th International Conference on Recent Advances in Space Technologies (RAST 2015). 